\title{
"Examining the role of sharia supervisory board attributes in reducing financial statement fraud by Islamic banks"
}

\begin{tabular}{|c|c|}
\hline \multirow{4}{*}{ AUTHORS } & Indah Anisykurlillah iD https://orcid.org/0000-0003-1307-5506 \\
\hline & Prabowo Yudo Jayanto id https://orcid.org/0000-0002-5532-8324 \\
\hline & Hasan Mukhibad iD https://orcid.org/0000-0001-8979-5169 \\
\hline & Umi Widyastuti iD https://orcid.org/0000-0002-5871-3578 \\
\hline ARTICLE INFO & $\begin{array}{l}\text { Indah Anisykurlillah, Prabowo Yudo Jayanto, Hasan Mukhibad and Umi } \\
\text { Widyastuti (2020). Examining the role of sharia supervisory board attributes in } \\
\text { reducing financial statement fraud by Islamic banks. Banks and Bank Systems, } \\
\text { 15(3), 106-116. doi:10.21511/bbs.15(3).2020.10 }\end{array}$ \\
\hline DOI & http://dx.doi.org/10.21511/bbs.15(3).2020.10 \\
\hline RELEASED ON & Wednesday, 09 September 2020 \\
\hline RECEIVED ON & Wednesday, 04 March 2020 \\
\hline \multirow[t]{2}{*}{ ACCEPTED ON } & Thursday, 27 August 2020 \\
\hline & \begin{tabular}{|l|}
$(\mathrm{cc}) \mathrm{EY}$ \\
\end{tabular} \\
\hline LICENSE & $\begin{array}{l}\text { This work is licensed under a Creative Commons Attribution } 4.0 \text { International } \\
\text { License }\end{array}$ \\
\hline JOURNAL & "Banks and Bank Systems" \\
\hline ISSN PRINT & $1816-7403$ \\
\hline ISSN ONLINE & $1991-7074$ \\
\hline PUBLISHER & LLC "Consulting Publishing Company "Business Perspectives" \\
\hline FOUNDER & LLC "Consulting Publishing Company "Business Perspectives" \\
\hline
\end{tabular}

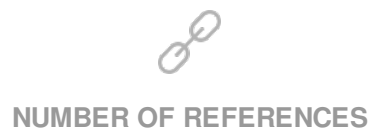

62

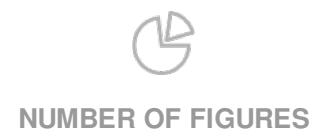

0

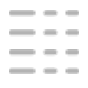

NUMBER OF TABLES

3

(C) The author(s) 2021. This publication is an open access article. 


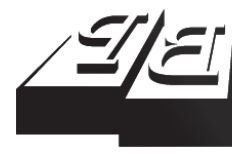

\section{BUSINESS PERSPECTIVES}

LLC "CPC "Business Perspectives" Hryhorii Skovoroda lane, 10, Sumy, 40022, Ukraine www.businessperspectives.org

Received on: $4^{\text {th }}$ of March, 2020 Accepted on: 27 th of August, 2020 Published on: $9^{\text {th }}$ of September, 2020

(c) Indah Anisykurlillah, Prabowo Yudo Jayanto, Hasan Mukhibad, Umi Widyastuti, 2020

Indah Anisykurlillah, M.Si., Lecturer Economics Faculty, Universitas Neger Semarang, Indonesia. (Corresponding author)

Prabowo Yudo Jayanto, M.S.A. Lecturer, Economics Faculty, Universitas Negeri Semarang, Indonesia.

Hasan Mukhibad, M.Si., Lecturer Economics Faculty, Universitas Negeri Semarang, Indonesia.

Umi Widyastuti, M.Si., Lecturer, Economics Faculty, Universitas Negeri Jakarta, Indonesia.
Indah Anisykurlillah (Indonesia), Prabowo Yudo Jayanto (Indonesia), Hasan Mukhibad (Indonesia), Umi Widyastuti (Indonesia)

\section{EXAMINING THE ROLE} OF SHARIA SUPERVISORY BOARD ATTRIBUTES IN REDUCING FINANCIAL STATEMENT FRAUD BY ISLAMIC BANKS

\begin{abstract}
Sharia Supervisory Board (SSB) plays an important role in implementing Islamic law in Islamic banks, including fraud prevention. This ungodly act, also known as haram, is highly forbidden in Islam, as evidenced in the holy book of Al Qur'an. Therefore, this study was conducted to provide evidence on the role of SSB attributes (number of members, expertise, cross-membership, educational level, attendance of meeting, tenure) in preventing fraud. This study used 11 Islamic banks in Indonesia as research samples that were observed during 2014-2018. Data were analyzed using the ordinary least squares (OLS) method. The research findings from this study showed that the number of members, cross-membership, education level, attendance of meetings, and SSB tenure were not proven to reduce fraud. SSB's expertise in accounting/finance had a negative influence on financial statement fraud. The implication of the study is that SSB's expertise helps banks to effectively carry out their duties, namely detecting financial statement fraud. SSB acts as an independent control mechanism that states that all bank activities are in line with Islamic law and also avoid financial statement fraud.
\end{abstract}

\section{Keywords} fraud, board attributes, Islamic bank, Islamic ethics, agency problems

\section{JEL Classification G32, G24}

\section{INTRODUCTION}

The occurrence of fraud in Islamic banks is very unfortunate due to the use of Islamic law as an operational guideline. Many verses of the al-Qur'an forbid the acts of fraud, either in the form of theft, as written in Qur'an 2: 188, or manipulation (QS 16: 116). However, crimes prohibited in Islam still occur on entities guided by Islamic laws, such as the South African Islamic Bank, The Ihlas Finance House, Dubai Islamic Bank; Bank Taqwa, Faisal Islamic Bank, Kuwait Finance House, International Islamic Bank of Denmark, and Bank Islam Malaysia Berhad (BIMB) (Awang \& Ismail, 2018; Yusuf, Ahmad, \& Razimi, 2016; Mukminin, 2018; Rahman \& Anwar, 2014a). Similar cases also occurred in Indonesia, such as fraud cases at Bank Syariah Mandiri, Bank Jateng Syariah, and Bank Jabar Banten Syariah (Astuti, Rozali, \& Cakhyaneu, 2019; Mukhibad, 2017).

The occurrence of fraud in Islamic banks has become a topic of debate, with common questions, such as "Does fraud also occur in Islamic and conventional banks?", generally asked (Fathi, Ghani, Said, \& Puspitasari, 2017). However, assuming that the conditions are similar, this is very ironic, because an Islamic bank tends to promote fidelity, openness, and transparency on its performance towards all of the stakeholders. Conversely, the rapid growth of banks tends to attract fraud (Vania, Nugraha, \& Nugroho, 2018). 
According to many literatures, fraud consists of three forms, namely fraudulent statements, corruption, and assets misappropriation (Holtfreter, 2005; Nigrini, 2019; Said, Alam, Karim, \& Johari, 2018; Westhausen, 2017). Association of Certified Fraud Examiners (AFCE) reported that these three types of illegal activities often occur as misappropriate assets, corruption, and Financial Statement Fraud (ACFE, 2018). However, Rahman \& Anwar (2014) stated that fraudulent financial statements often occur in Islamic banks. Financial statement fraud creates a false view of the performance of an Islamic bank (Mukhibad \& Nurkhin, 2019) and leads to an unfair profit sharing calculation for the depositor.

Previous studies examined financial statement fraud in Islamic banks with limited literature data obtained from disclosing the factors that influence fraud using the psychological approach of respondents conducted by Rahman and Anwar (2014), Fathi, Ghani, Said, and Puspitasari (2017), and Suryanto and Ridwansyah (2016), and literature study (see Astuti, Rozali, \& Cakhyaneu, 2019; Yusuf, Ahmad, \& Razimi, 2016; Mukminin, 2018; Rahman \& Anwar, 2014). Meanwhile, Mukhibad and Nurkhin (2019) used corporate governance as a factor influencing earnings management in Islamic banks.

However, this research used corporate governance and financial statement fraud in Islamic banks for its analysis. These factors were used due to their ability to explain the financial statement fraud as a product of the Chief Executive Officer (CEO), and other directors are institutional banks. The corporate governance approach used to explain financial statement fraud was recommended by Rezaee (2005), Farber (2005), Chen, Firth, Gao, and Rui (2006), Halbouni, Obeid, and Garbou (2016), In'airat (2015), and Uzun, Szewczyk, and Varma (2004).

Besides, this study focused on the role of the Sharia Supervisory Board (SSB) in reducing financial statement fraud. The reasons for using SSB are as follows:

1) it is a unique board in Islamic entities;

2) SSB plays an important role in implementing Islamic law;

3) SSB is an independent board;

4) SSB reduces agency costs; and

5) financial statement fraud occurs due to agency problems.

Subsequently, several attributes, previously used in other studies, were utilized to enhance SSB in carrying out their duties. These include the number of members, cross-membership, expertise, level of education, attendance of meetings, and tenure. All of these attributes are adopted from previous studies. The research problems are whether the SSB attributes (as measured by number of members, cross-membership, expertise, level of education, attendance of meetings, and tenure) negatively affect financial statement fraud?

This study presents a structure of the importance of studying financial statement fraud in Islamic banks, as well as theories and hypotheses deduced from previous studies. The methods used are presented to limit the study and continue with the results and conclusions.

\section{LITERATURE REVIEW}

According to the analysis, managing large and complex business entities results in separation between owners and directors due to the mismanagement of company assets. For instance, a company owner acquires benefits from increased value and dividends, while a director receives a good salary or remuneration scale. However, this relationship becomes flawed when the director is unable to carry out their duties adequately, such as by committing fraud.

Experts have described fraud in three forms, namely corruption, asset misappropriation, and financial statement fraud (Holtfreter, 2005; Nigrini, 
2019; Westhausen, 2017). Asset misappropriation occurs when employees misuse or divert company resources for their gain. Crime occurs when a person provides or offers something of great value to others that affect their judgment or behavior. At the same time, financial statement fraud takes place when fraudsters present manipulated financial statements capable of misleading investors, auditors, and analysts on the true financial condition of the entity (Nigrini, 2019).

Fraud is a criminal act that negatively affects all stakeholders. Bales and Fox (2010) stated that before now, the incidence of fraud was on the increase and still tends to rise. Many parties consider that fraud occurs because of the low ethics of the perpetrators (Sow, Basiruddin, Mohammad, \& Rasid, 2018), while others believe that people participate in this act due to poor supervision (Abdullahi \& Mansor, 2018; Nawawi \& Salin, 2018). Chen, Firth, Gao, and Rui (2006), Eferakeya, Enaibre, and Offor (2016), Farber (2005), Halbouni, Obeid, and Garbou (2016), and Salin, Ab Manan, Kamaluddin, and Nawawi (2017) used corporate governance factors to explain fraud. These different points of view led to creating many factors for the proper definition of fraud.

Religion contains directives that form the ethical orientation of a society. According to Rice (2006), there are real and ideal differences between Muslim and non-Muslim communities in terms of teachings. However, empirical evidence shows that fraud also occurs in religious-based business entities, such as Islamic banks (Awang \& Ismail, 2018; Yusuf, Ahmad, \& Razimi, 2016; Mukminin, 2018; Rahman \& Anwar, 2014a; Astuti, Rozali, \& Cakhyaneu, 2019; Mukhibad, 2017).

This study aims to explain the causes of financial statement fraud in Islamic banks. The study considers the specific corporate governance mechanism in Islamic banks, namely the sharia supervisory board, which is an independent board for Islamic entities (Alabbad, Hassan, \& Saba, 2019) and has the obligation to provide supervision or auditng to directors and other boards (Alsartawi, 2019; AlShattarat \& Atmeh, 2016; Mukhibad \& Nurkhin, 2019). To explain the role of sharia supervisory board, this study uses five attributes, namely number of members, expertise, cross-member- ship, education level, attendance at meetings, and tenure. Thus, the aim of the study is to prove the effect of SSB's attributes on reducing financial statement fraud in Islamic banks.

\section{HYPOTHESES DEVELOPMENT}

To solve this problem, this research examines the role of SSB in reducing financial statement fraud. This postulate was built due to the following reasons: SSB plays a unique role in Islamic entities, it ensures that banks carry out their operation in accordance with Sharia rules, and SSB has the duty to provide consulting and auditor services (Farook \& Roman, 2007; Farook, Hassan \& Lanis, 2011). Based on this reason, it is believed that, first, SSB, as a consultant, provides advice to directors and other boards in the implementation of Islamic law and ethics. Quttainah and Almutairi (2017) stated that SSB plays a role in improving management ethics and reducing agency conflicts. Second, SSB as an auditor (Alsartawi, 2019) helps in evaluating the overall performance of banks in the implementation of Islamic ethics. Quttainah and Almutairi (2017) and Quttainah Song, and Wu (2013) show that SSB has an impact on the implementation of Islamic ethics (Nawaz, 2019). Therefore, this research used these SSB attributes as a factor to reduce fraud and to assist employees in carrying out their duties effectively.

The first attribute is the number of SSB members. In agency theory, small boards are easily controlled by managers, therefore, an increase beyond seven or eight people tends to function effectively. Salleh and Othman (2016) reported that the tendency to carry out financial statement fraud is higher when more directors hold meetings concurrently. Therefore, banks with many SSBs are more effective in carrying out their duties than those with fewer numbers. This also allows them to increase supervision and compliance (Almutairi \& Quttainah, 2017), carry out the distribution of tasks, and reduce the potential of financial statement fraud. This has led to the following hypothesis:

H1: The number of SSB members has a negative influence on financial statement fraud. 
SSB is an independent board that acts as a supervisor and consultant manager in implementing Islamic laws in a bank. It influences the functions of auditors in carrying out their duties. Therefore, SSB's expertise in accounting/finance is needed (Almutairi \& Quttainah, 2017). According to Almutairi and Quttainah (2017), Matoussi and Grassa (2012), and Nomran, Haron, and Hassan (2017), the ratio of SSB in increasing banking performance is related to the board's competency in carrying out their duties. This led to the second hypothesis:

\section{H2: SSB's expertise negatively affects financial statement fraud.}

Another factor that increases the effectiveness of SSB in carrying out their duties is cross-membership. Those that work in several Islamic banks tend to gain knowledge and expertise by sharing experiences. This enables them to coordinate with each other, exchange ideas on a case consulted by a manager. This activity tends to have an impact on increasing the understanding and expertise of SSB. Bukair and Rahman (2013) stated that there are five reasons of SSB cross-membership to improve performance, which are as follows:

1) it compares the knowledge obtained by several entities;

2) decisions made by one SSB are part of the information as a basis for decision making for others;

3) it acts as an information channel on business practices;

4) the membership is preferred by banks due to its knowledge and credibility; and

5) members tend to adopt the knowledge obtained secretly and explicitly from an entity in another.

SSB with cross-membership discusses the implementation of Islamic law in banking (Farook \& Roman, 2007). Fakhruddin and Jusoh (2018) stated that cross membership has a positive influence on Shariah compliance. This led to the third hypothesis:

\section{H3: SSB's cross-membership has a negative influ- ence on financial statement fraud.}

Another indicator that is widely used by experts as a factor influencing the effectiveness of the board is its education level. Ingley and Van der Walt (2001) stated that highly educated directors tended to offer more sources of innovative ideas and policy development because of their intellectual abilities, experience, good judgment, and integrity. The heterogeneity of the board's educational background provides different perspectives and cognitive paradigms that influence the development of vocational and social contacts of organizational behavior and performance (Ingley \& Van der Walt, 2001).

Furthermore, the results are consistent with the ability of the board's educational levels to improve performance. Darmadi (2013) stated that the educational qualifications of the board and CEO members were, to some extent, important in explaining ROA or Tobin's-Q. Furthermore, CEOs with degrees from well-known universities performed better than those without these qualifications. Saidu (2019) also stated that the education qualification possessed by the CEO is important to increase profitability. Almutairi and Quttainah (2017) also supported this finding and proved that SSB education had a positive influence on ROA, ROE, and Tobin-Q. However, Nomran, Haron, and Hassan (2018) reported that the ratio of SSB with doctor qualifications had a negative influence on bank performance. This led to the fourth hypothesis:

H4: The level of education has a negative influence on financial statement fraud.

The meeting is defined as the coordination between SSB members, managers, and commissioners. It is part of the evidence that this attribute has provided its consulting services because it provides each member with an opinion, policy, or case in the bank. Conversely, its implementation is an opportunity for managers to provide information and consult strategic policies on SSB. Therefore, the more often SSBs hold meetings, the more effective the company's policies, thereby improving bank performance.

Vafeas (1999), Oseit and Ntim (2011) and Alsartawi (2019) have provided evidence of this relationship. 
For instance, Vafeas (1999) and Oseit and Ntim (2011) stated that the number of board meetings had the ability to increase the value of an entity. However, this result was disputed by Hanh, Ting, Kweh, and Hoanh (2018), who stated that the frequency of meetings often takes up time, therefore, it has a negative impact on performance. Meetings require fees, which add to the burden of the entity. Subsequently, this debate concluded that the quality of meetings was important, and not the frequency. Therefore, this led to the fifth hypothesis:

H5: SSB's attendance at meetings has a negative influence on financial statement fraud.

The real debate in implementing corporate governance is associated with the tenure board. According to Chen, Firth, Gao, and Rui (2006), boards with long tenure allow members to learn and gain expertise, therefore, it provides better expertise. In line with previous opinions, RegueraAlvarado and Bravo (2017) stated that boards with old directors had a positive influence on a company's business knowledge and further improved performance. However, following a study involving companies in the USA, Reguera-Alvarado and Bravo (2017) found that board tenure had a positive influence on firm performance. Therefore, this led to the sixth hypothesis:

H6: SSB's tenure has a negative influence on $f$ nancial statement fraud.

\section{METHODS}

Data were obtained from Islamic commercial banks in Indonesia. The purposive sample method was used from 11 banks with 5-year observations (2014-2018) and analyzed using the ordinary least square (OLS) method.

Financial statement fraud variables were measured by adopting earning management measurement methods developed by Mersni and Othman (2016) using DLLP. This was used by a bank manager to regulate and evaluate the non-discretionary and discretionary value of $L L P$.

$$
\begin{aligned}
& D L L P=\text { discretionary } L L P+ \\
& + \text { non-discretionary } L L P,
\end{aligned}
$$

$$
\begin{aligned}
& L L P_{i t}=\beta_{0}+\beta_{1} N P L_{i t-1}+ \\
& +\beta_{2} \Delta N P L_{i t}+\beta_{3} \Delta T L_{i t}+€_{i t},
\end{aligned}
$$

where $L L P_{i t}$ is total allowance for loans, investment or financing for bank $i$ in year $t ; N P L_{i t-1}$ is initial balance of problem loans for bank $i$ in year $t ; \Delta \mathrm{NPL}_{i t}$ is changes in the value of problem loans for bank $i$ in year t; and $\Delta \mathrm{TL}_{i t}$ is changes in the total value of loans for bank $i$ in year $t$.

DLLP score showing that there was no tendency of fraud was the score approaching zero (this could be a positive or negative score). To let this DLLP score be one-way, this study eliminated negative numbers with the following formula:

$$
S Q R T D L L P=\sqrt{D L L P^{2}}
$$

The SSB was measured by the number of members, with the expertise determined by the ratio of those educated on finance/accounting. Furthermore, cross-membership was measured by the average SSB member sit as SSB on other banks. The education level was measured by the average level of educated SSB members, where scores of 1, 2, and 3 were given to undergraduates (bachelor degree), graduates (master degree), and postgraduates (doctoral degree), respectively. The meeting attendance and tenure were measured by the average ratio of all SSB members and tenure on an annual basis. In this study, assets were used as a control variable.

\section{RESULTS}

The descriptive test results show that the average value of $L L P$ was 3.59 , with a maximum of 24.98. The bank is likely to carry out financial statement fraud, assuming the value is close to zero. Furthermore, the minimum $L L P, 0.0024$, was found in Bank Muamalat Indonesia in 2018. The average meeting attendance showed that SSB in Indonesia had a good attendance percentage because $88.74 \%$ were in attendance, with a minimum of $50 \%$.

The average tenure of SSB was 7.06 years, however, some ruled for 17 years. Similarly, the number of SSB members is between 2 and 3 people, with a 
Table 1. Descriptive analysis

\begin{tabular}{|c|c|c|c|c|c|c|c|c|}
\hline & LLP & Size & $\begin{array}{c}\text { Cross- } \\
\text { membership }\end{array}$ & Expert & Education level & Meeting & Tenure & Assets \\
\hline Max & 24.9831 & 3 & 5.5 & 0 & 3 & 100.00 & 17 & 32.2195 \\
\hline Min & 0.0024 & 2 & 2 & 0.666667 & 1 & 50.00 & 2 & 13.6002 \\
\hline Mean & 3.5938 & 2.2273 & 3.3144 & 0.263636 & 2.3333 & 88.74 & 7.06 & 28.2931 \\
\hline St. dev & 5.1155 & 0.4191 & 0.9329 & 0.283264 & 0.4509 & 17.23 & 3.34 & 4.7827 \\
\hline
\end{tabular}

maximum of $50 \%$ of the total number of directors in accordance with the law stipulated by the FSA. The average value at 2.22 showed that most of the samples had a total of two people, while the average cross-membership of 3.3 with a maximum number of 5.5, shows that it contains three Sharia entities. SSB background viewed from the level of education showed an average value of 2.33 with minimum and maximum values of 1 and 3 . This data showed that most of the SSBs had a graduate education.

The testing of causality between variables, as shown in Table 2, indicates that none was above 0.8 . This means that all variables used in this research are independent.

The test results using OLS are presented in Table 3, and they showed that SSB expertise had a significance of less than 0.01 with a coefficient of -0.664 . Similarly, the Asset Variable had a significance value of less than 0.10 with a coefficient of 0.227 , while others, such as the number of SSB members, meeting attendance, cross-membership, ten- ure, and education level, were above 0.10 . This fact showed that the SSB expertise variable and the amount of assets had a negative and positive influence on financial statement fraud, respectively.

\section{DISCUSSION}

The results of this study showed that a large number of SSBs were unable to control financial statement fraud. This is because banks are more effective in conducting supervision and consultation, thereby preventing the occurrence of fraud. Almutairi and Quttainah (2017), Nomran, Haron, and Hassan (2018), Hakimi, Rachdi, Mokni, and Hssini (2018), and Nawaz (2017) agreed that the number of SSBs influenced the quality of services provided. This, however, is related to the supervision of the director committing fraud. Therefore, the quality of services improved due to the increased number of SSB members related to supervision and consultation in improving performance, profitability (Almutairi \& Quttainah, 2017; Nomran, Haron, \& Hassan, 2018), social

Table 2. Variables causality test

\begin{tabular}{|c|c|c|c|c|c|c|c|c|}
\hline & LLP & Size & $\begin{array}{c}\text { Cross- } \\
\text { membership }\end{array}$ & Expert & $\begin{array}{c}\text { Education } \\
\text { level }\end{array}$ & Meeting & Tenure & Assets \\
\hline LLP & 1 & -0.033 & 0.066 & -0.17 & -0.123 & -0.532 & 0.018 & 0.114 \\
\hline Size & -0.033 & 1 & 0.302 & 0.243 & 0.16 & -0.125 & 0.234 & -0.469 \\
\hline $\begin{array}{l}\text { Cross- } \\
\text { membership }\end{array}$ & 0.066 & 0.302 & 1 & 0.274 & -0.174 & 0.202 & 0.277 & -0.216 \\
\hline Expert & -0.17 & 0.243 & 0.274 & 1 & 0.017 & 0.253 & 0.242 & 0.074 \\
\hline Education level & -0.123 & 0.16 & -0.174 & 0.017 & 1 & -0.069 & 0.15 & 0.108 \\
\hline Meeting & -0.532 & -0.125 & 0.202 & 0.253 & -0.069 & 1 & 0.021 & 0.12 \\
\hline Tenure & 0.018 & 0.234 & 0.277 & 0.242 & 0.15 & 0.021 & 1 & -0.258 \\
\hline Ln assets & 0.114 & -0.469 & -0.216 & 0.074 & 0.108 & 0.12 & -0.258 & 1 \\
\hline
\end{tabular}

Table 3. Ordinary least square test

\begin{tabular}{|c|c|c|c|c|c|c|c|}
\hline & Size & $\begin{array}{c}\text { Cross- } \\
\text { membership }\end{array}$ & Expert & $\begin{array}{c}\text { Education } \\
\text { level }\end{array}$ & Tenure & Meeting & Assets \\
\hline Path coefficients & 0.02 & 0.12 & -0.50 & -0.05 & 0.07 & -0.23 & 0.19 \\
\hline P-values & 0.45 & 0.20 & $<0.001^{* * *}$ & 0.36 & 0.33 & 0.05 & $0.09 *$ \\
\hline
\end{tabular}

Note: $* * *$ significant at $1 \%, * *$ significant at $5 \%$, and $*$ significant at $10 \%$. 
performance (Bukair \& Rahman, 2013; Fitriyah \& Oktaviana, 2007; Almutairi \& Quttainah, 2016, Mallin, Farag, \& Ow-Yong, 2014) and risk disclosure (Srairi, 2018; Saufanny \& Khomsatun, 2017; Elamer, Ntim, Abdou, Zalata, \& Elmagrhi, 2019).

SSB cross-membership was proved to have no negative influence on financial statement fraud due to the inability of entities to conduct discussions related to its identification. Nomran, Haron, and Hassan (2018) state that there are indications that SSB positions on several entities do occur on topics related to product policies that lead to profitability. Therefore, the discussion on financial statement fraud has not been effectively conducted by SSB.

The expertise of SSB in the field of finance/accounting was proven to have a negative influence on financial statement fraud, which is in line with the studies by Grassa (2016), Nomran and Haron, 2019), Rahman and Haron (2019), and Nomran, Haron, and Hassan (2017). The function of SSB as a provider of supervisory services and consulting services for managers and other boards needs expertise in the fields of business, economics, finance, and Sharia. It is because Islamic banks have a goal to obtain benefits that are in accordance with Sharia and in compliance with business objectives. Furthermore, the results of this study have shown that SSB's expertise in finance/ accounting prevents directors from conducting financial statement fraud. An SSB with doctoral education level is not automatically able to identify and prevent managers from conducting financial statement fraud. Therefore, the prevention of this behavior can only be carried out by experts in the field of accounting. In the sample, many SSBs have doctoral backgrounds outside the field of accounting, such as ushuludin (religious sciences), Islamic education, and Sharia, therefore, it does not provide competent students.

The results of this study also found that SSB tenure had no influence on financial statement fraud (Chen, Firth, Gao, \& Rui, 2006), however, it positively influenced business expertise and knowledge (Reguera-Alvarado \& Bravo, 2017). This finding also confirms that the SSB's knowledge and expertise in detecting financial statement fraud have not increased due to the addition of tenure.

The facts also proved that the amount of assets had a positive influence on the financial statement fraud because it encourages directors to improve their performance and accountability. Sometimes, the director's inability to manage assets triggers them to commit financial statement fraud. This study reinforced the findings of Yulistyawati, Suardikha, and Sudana (2019), who used the amount of assets as a proxy to measure rationalization, and found that it had a significant influence on financial statement fraud. A director commits this by increasing or decreasing the level of accounting accruals that exist in the accounts of inventory, receivable, accrued income, costs, and other accounts to achieve the desired profit. Therefore, large assets are triggered by large accrual accounts, hence, the relationship between assets and financial statement fraud is positive.

\section{CONCLUSION}

This study focused on the role of SSB in reducing financial statement fraud of Islamic banks by measuring its role with attributes such as number of members, cross-membership, expertise, level of education, and meeting attendance. SSB was used due to its ability to ensure that banks comply with Sharia law by prohibiting financial statement fraud. The results showed that only SSB's expertise in accounting/ finance had a negative influence on financial statement fraud.

This finding has confirmed previous studies that stated that SSB's expertise in finance/accounting is needed as a complement in Islamic banks. Moreover, banks need SSB supervisors and consultants as directors and board members. This study recommends that Indonesian regulators (Financial Services Authority - Otoritas Jasa Keuangan/OJK) improve SSB's expertise in the field of accounting/finance. The expertise in finance/accounting caused by SSB can identify financial statement fraud that occurs in an Islamic bank. 
This study focuses on the role of SSB in influencing financial statement fraud. SSB is one of the independent boards, which also has the task of supervising the director to achieve the goals of an entity. Further studies are needed to further explore the use of other board attributes to explain financial statement fraud.

\section{AUTHOR CONTRIBUTIONS}

Conceptualization: Indah Anisykurlillah, Prabowo Yudo Jayanto, Hasan Mukhibad.

Data curation: Indah Anisykurlillah, Prabowo Yudo Jayanto, Hasan Mukhibad, Umi Widyastuti.

Formal analysis: Indah Anisykurlillah, Prabowo Yudo Jayanto, Hasan Mukhibad,

Funding acquisition: Indah Anisykurlillah, Prabowo Yudo Jayanto.

Investigation: Indah Anisykurlillah, Prabowo Yudo Jayanto.

Methodology: Indah Anisykurlillah, Prabowo Yudo Jayanto, Hasan Mukhibad.

Project administration: Indah Anisykurlillah.

Resources: Indah Anisykurlillah, Prabowo Yudo Jayanto.

Software: Indah Anisykurlillah, Hasan Mukhibad, Umi Widyastuti.

Supervision: Indah Anisykurlillah, Prabowo Yudo Jayanto.

Validation: Indah Anisykurlillah, Hasan Mukhibad, Umi Widyastuti.

Visualization: Indah Anisykurlillah, Prabowo Yudo Jayanto, Umi Widyastuti.

Writing - original draft: Indah Anisykurlillah, Prabowo Yudo Jayanto, Hasan Mukhibad.

Writing - reviewing \& editing: Indah Anisykurlillah, Umi Widyastuti.

\section{REFERENCES}

1. Abdullahi, R., \& Mansor, N.

(2018). Fraud prevention initiatives in the Nigerian public sector: Understanding the relationship of fraud incidences and the elements of fraud triangle theory. Journal of Financial Crime, 25(2), 527-544. https://doi. org/10.1108/JFC-02-2015-0008

2. Alabbad, A., Hassan, M. K., \& Saba, I. (2019). Can Shariah board characteristics influence risk-taking behavior of Islamic banks? International Journal of Islamic and Middle Eastern Finance and Management, 12(4), 469-488. https://doi.org/10.1108/ IMEFM-11-2018-0403

3. Almutairi, A. R., \& Quttainah, M. A. (2017). Corporate governance: Evidence from Islamic banks. Social Responsibility Journal, 13(3), 601-624. https://doi.org/10.1108/ SRJ-05-2016-0061

4. Alsartawi, A. M. (2019). Performance of Islamic banks: Do the frequency of Sharīah supervisory board meetings and independence matter? ISRA International Journal of Islamic Finance, 11(2), 303-321. https:// doi.org/10.1108/ijif-05-2018-0054
5. AlShattarat, W. K., \& Atmeh, M. A. (2016). Profit-sharing investment accounts in Islamic banks or mutualization, accounting perspective. Journal of Financial Reporting and Accounting, 14(1), 30-48. https://doi.org/10.1108/ jfra-07-2014-0056

6. Astuti, M. A., Rozali, R. D. Y., \& Cakhyaneu, A. (2019). Prevention of Fraud in Sharia Banking in Indonesia through Implementation of Sharia Corporate Governance. The 2nd International Conference on Islamic Economics, Business, and Philanthropy (ICIEBP) Theme: "Sustainability and Socio Economic Growth," 2019, 183-202. https:// doi.org/10.18502/kss.v3i13.4205

7. Awang, Y., \& Ismail, S. (2018). Determinants of financial reporting fraud intention among accounting practitioners in the banking sector. International Journal of Ethics and Systems, 34(1), 32-54. https://doi. org/10.1108/ijoes-05-2017-0080

8. Bales, K., \& Fox, T. L. (2010). Evaluating a trend analysis of fraud factors. Journal of Finance \& Accountancy, 5(2), 1-10. Retrieved from http://ezproxy.library.capella. edu/login?url=http://search.ebscohost.com/login.aspx?direct=true\& $\mathrm{db}=\mathrm{bth} \& \mathrm{AN}=57522926 \&$ site $=$ eho st-live\&scope $=$ site

9. Bukair, A. A., \& Rahman, A. A. (2013). The Influence of the Shariah Supervision Board on Corporate Social Responsibility Disclosure by Islamic Banks of Gulf Co-Operation Council Countries. Asian Journal of Business and Accounting, 6(2), 65 104. https://doi.org/10.5296/jmr. v7i2.6989

10. Chen, G., Firth, M., Gao, D. N., \& Rui, O. M. (2006). Ownership structure, corporate governance, and fraud: Evidence from China. Journal of Corporate Finance, 12(3), 424-448. https://doi. org/10.1016/j.jcorpfin.2005.09.002

11. Darmadi, S. (2013). Board members' education and firm performance: evidence from a developing economy. International Journal of Commerce and Management, 23(2), 113-135. https://doi. org/10.1108/10569211311324911 
12. Eferakeya, I., Enaibre, I. F., \& Offor, N. T. (2016). The relationship between corporate governance and fraud prevention in Nigeria: a perceptual view. Journal of Social and Management Sciences, 11(3), 1-18. Retrieved from https:// pdfs.semanticscholar.org/0779/ ec57a4c2c9a3f35336715df411c8d47da8e9.pdf

13. Elamer, A. A., Ntim, C. G., Abdou, H. A., Zalata, A. M., \& Elmagrhi, M. (2019). The impact of multilayer governance on bank risk disclosure in emerging markets: the case of Middle East and North Africa. Accounting Forum, 43(2), 246-281. https://doi.org/10.1080/0 1559982.2019.1576577

14. Fakhruddin, I., \& Jusoh, M. A. (2018). Influence of Sharia Supervisory Board Characteristics on the Shariah Compliance. Advances in Social Science, Education and Humanities Research, 231(AMCA), 355-357. https://doi.org/10.2991/amca18.2018.97

15. Farber, D. B. (2005). Restoring trust after fraud: Does corporate governance matter? Accounting Review, 80(2), 539-561. https://doi. org/10.2308/accr.2005.80.2.539

16. Farook, S., \& Roman, L. (2007). Banking on Islam? Determinants of Corporate Social Responsibility Disclosure. Islamic Economics and Finance, 2(17), 355-388. Retrieved from http://www. iefpedia.com/english/wp-content/ uploads/2011/02/Advances-inIslamic-Economics-Finance\%E2\%80\%93-Munawar-Iqbal-Salman-Syed-Ali-Dadang-Muljawan. pdf $\#$ page $=230$

17. Farook, S., Hassan, M. K., \& Lanis, R. (2011). Determinants of Corporate Social Responsibility Disclosure: The Case of Islamic Banks. Journal of Islamic Accounting and Business Research, 2(2), 114-141. https://doi. org/10.1108/17590811111170539

18. Fathi, W. N. I. W. M., Ghani, E. K., Said, J., \& Puspitasari, E. (2017). Potential employee fraud scape in Islamic banks: The fraud triangle perspective. Global Journal AlThaqafah, 7(2), 79-93. Retrieved from http://www.gjat.my/ gjat122017/GJAT122017-3.pdf

19. Fitriyah, F., \& Oktaviana, U. O. (2007). Relevance of Financial Performance and Good Corporate Governance Determinant of Sustainability Corporate Social Responsibility Disclosure in Islamic Bank in Indonesia. International Journal of Nusantara Islam, 1(2), 22-37. https://doi. org/10.15575/ijni.v1i2.23

20. Grassa, R. (2016). Corporate governance and credit rating in Islamic banks: Does Shariah governance matters? Journal of Management \& Governance, 20, 875-906. https://doi.org/10.1007/ s10997-015-9322-4

21. Hakimi, A., Rachdi, H., Mokni, R. B. S., \& Hssini, H. (2018). Do board characteristics affect bank performance? Evidence from the Bahrain Islamic banks. Journal of Islamic Accounting and Business Research, 9(2), 251-272. https://doi org/10.1108/JIABR-06-2015-0029

22. Halbouni, S. S., Obeid, N., \& Garbou, A. (2016). Corporate governance and information technology in fraud prevention and detection: Evidence from the UAE. Managerial Auditing Journal, 31(6-7), 589-628. https://doi. org/10.1108/MAJ-02-2015-1163

23. Hanh, L. T. M., Ting, I. W. K., Kweh, Q. L., \& Hoanh, L. T. H. (2018). Board meeting frequency and financial performance: A case of listed firms in Vietnam. International Journal of Business and Society, 19(2), 464-472. Retrieved from https://repository.cud.ac.ae/handle/20.500.12519/134

24. Holtfreter, K. (2005). Is occupational fraud "typical" white-collar crime? A comparison of individual and organizational characteristics. Journal of Criminal Justice, 33(4), 353-365. https://doi. org/10.1016/j.jcrimjus.2005.04.005

25. In'airat, M. (2015). The Role of Corporate Governance in Fraud Reduction-A Perception Study in the Saudi Arabia Business Environment. Journal of Accounting and Finance, 15(2), 119-128. Retrieved from https:// www.semanticscholar.org/ paper/The-Role-of-CorporateGovernance-in-Fraud-Study-inIn\%27airat-Rushd/2719b5e0ef9d5 34f430c8e392a35c05b47f33870

26. Ingley, C. B., \& Van der Walt, N. T. (2001). The Strategic Board: the changing role of directors in developing and maintaining corporate capability. Corporate Governance, 9(3), 174-185. https:// doi.org/10.1111/1467-8683.00245

27. Mallin, C., Farag, H., \& OwYong, K. (2014). Corporate Social Responsibility and Financial Performance in Islamic Banks. Journal of Economic Behavior and Organization, 103, 21-38. https:// doi.org/10.1016/j.jebo.2014.03.001

28. Matoussi, H., \& Grassa, R. (2012). Is Corporate Governance Different for Islamic Banks? A Comparative Analysis Between the Gulf Cooperation Council Context and The Southeast Asia Context (Working Papers No. 734). Economic Research Forum, Egypt. Retrieved from https://econpapers. repec.org/paper/ergwpaper/734. htm

29. Mersni, H., \& Othman, H. B. (2016). The impact of corporate governance mechanisms on earnings management in Islamic banks in the Middle East region. Journal of Islamic Accounting and Business Research, 7(4), 318348. https://doi.org/10.1108/ JIABR-11-2014-0039

30. Mukhibad, H. (2017). Maintaining Employees' Morality to Improve Internal Control in the Sharia Microfinance Institution. Walisongo: Jurnal Penelitian Sosial Keagamaan, 25(2), 507. https://doi. org/10.21580/ws.25.2.1924

31. Mukhibad, H., \& Nurkhin, A. (2019). Islamic Business Ethics Disclosure and Earnings Management - Evidence from Islamic Banks in Indonesia. Journal of Islamic Finance, 8(2), 31-42. Retrieved from https://journals.iium.edu.my/iiibf-journal/ index.php/jif/article/view/337

32. Mukminin, K. (2018). How Close Islamic Banks Are To Global Fraud- Learnings From Dubai Islamic Bank in the Time of Sub- 
Prime Crisis. European Journal of Islamic Finance, 11, 1-9. https:// doi.org/10.13135/2421-2172/2762

33. Nawawi, A., \& Salin, A. S. A. P. (2018). Internal control and employees' occupational fraud on expenditure claims. Journal of Financial Crime, 25(3), 891-906. https://doi.org/10.1108/JFC-072017-0067

34. Nawaz, T. (2017). Momentum investment strategies, corporate governance and firm performance: an analysis of Islamic banks. Corporate Governance (Bingley), 17(2), 192-211. https://doi. org/10.1108/CG-03-2016-0052

35. Nawaz, T. (2019). Exploring the Nexus Between Human Capital, Corporate Governance and Performance: Evidence from Islamic Banks. Journal of Business Ethics, 157(2), 567-587. https://doi. org/10.1007/s10551-017-3694-0

36. Nigrini, M. J. (2019). The patterns of the numbers used in occupational fraud schemes. Managerial Auditing Journal, 34(5), 602-622. https://doi.org/10.1108/ MAJ-11-2017-1717

37. Nomran, N. M., \& Haron, R. (2019). Dual board governance structure and multi-bank performance: a comparative analysis between Islamic banks in Southeast Asia and GCC countries. Corporate Governance (Bingley), 19(6), 1377-1402. https://doi.org/10.1108/CG-102018-0329

38. Nomran, N. M., Haron, R., \& Hassan, R. (2017). Bank Performance and Shari'ah Supervisory Board Attributes of Islamic Banks: Does Bank Size Matter? Journal of Islamic Finance, 6(Special issue), 174-187. https:// doi.org/10.12816/0047348

39. Nomran, N. M., Haron, R., \& Hassan, R. (2018). Shariah supervisory board characteristics effects on Islamic banks' performance: Evidence from Malaysia. International Journal of Bank Marketing, 36(2), 290-304. https://doi.org/10.1108/IJBM-122016-0197

40. Oseit, K., \& Ntim, C. (2011) The impact of corporate board meetings on corporate performance in South Africa. African Review of Economics and Finance, 2(2), 83-103. Retrieved from https://www.african-review. com/journal/v2(2)june2011/Corporate $\% 20$ Performance $\% 20 \mathrm{in} \% 20$ SA.pdf

41. Quttainah, M. A., \& Almutairi, A. R. (2017). Corporate ethics: evidence from Islamic banks. Journal of Management and Governance, 21(4), 815-840. https://doi.org/10.1007/s10997 016-9360-6

42. Quttainah, M. A., Song, L., \& Wu, Q. (2013). Do Islamic Banks Employ Less Earnings Management? Journal of International Financial Management \& Accounting, 24(3). https://doi.org/10.1111/jifm.12011

43. Rahman, A. S., \& Haron, R. (2019). The Effect of Corporate Governance on Islamic Banking Performance: A Maqasid Shariah Index Approach on Indonesian Islamic Banks. Journal of Islamic Finance, 8(Special issue), 1-18. Retrieved from https://journals. iium.edu.my/iiibf-journal/index. php/jif/article/view/343

44. Rahman, R. A., \& Anwar, I. S. K. (2014). Effectiveness of Fraud Prevention and Detection Techniques in Malaysian Islamic Banks. Procedia - Social and Behavioral Sciences, 145, 97-102. https://doi.org/10.1016/j.sbspro.2014.06.015

45. Rahman, R. A., \& Anwar, I. S. K. (2014a). Types of Fraud among Islamic Banks in Malaysia. International Journal of Trade, Economics and Finance, 5(2), 176-179. https://doi.org/10.7763/ ijtef.2014.v5.365

46. Reguera-Alvarado, N., \& Bravo, F. (2017). The effect of independent directors' characteristics on firm performance: Tenure and multiple directorships. Research in International Business and Finance, 41, 590-599. https://doi. org/10.1016/j.ribaf.2017.04.045

47. Rezaee, Z. (2005). Causes, consequences, and deterrence of financial statement fraud. Critical Perspectives on Accounting, 16(3),
277-298. https://doi.org/10.1016/ S1045-2354(03)00072-8

48. Rice, G. (2006). Proenvironmental behavior in Egypt: Is there a role for Islamic environmental ethics? Journal of Business Ethics, 65(4), 373-390. https://doi.org/10.1007/s10551006-0010-9

49. Said, J., Alam, M. M., Karim, Z. A., \& Johari, R. J. (2018). Integrating religiosity into fraud triangle theory: findings on Malaysian police officers. Journal of Criminological Research, Policy and Practice, 4(2), 111-123. https://doi. org/10.1108/JCRPP-09-2017-0027

50. Saidu, S. (2019). CEO

characteristics and firm performance: focus on origin, education and ownership. Journal of Global Entrepreneurship Research, 9(1), 29. https://doi. org/10.1186/s40497-019-0153-7

51. Salin, A. S. A. P., Ab Manan, S. K., Kamaluddin, N., \& Nawawi, A. (2017). The role of Islamic ethics to prevent corporate fraud. International Journal of Business and Society, 18(S1), 113-128. Retrieved from https:// www.academia.edu/34450080/ THE_ROLE_OF_ISLAMIC_ETHICS TO_PREVENT_CORPORATE_FRAUD

52. Salleh, S. M., \& Othman, R. (2016). Board of Director's Attributes as Deterrence to Corporate Fraud. Procedia Economics and Finance, 35(16), 82-91. https://doi. org/10.1016/s2212-5671(16)000125

53. Saufanny, A. D., \& Khomsatun, S. (2017). Corporate Governance dan Pengungkapan ManaJemen Risiko Bank Syariah di Indonesia. Jurnal Akuntansi Dan Keuangan Islam, 5(1), 47-62. Retrieved from https://media.neliti.com/media/ publications/266292-corporategovernance-dan-pengungkapan ma-2a060b96.pdf

54. Sow, A. N., Basiruddin, R., Mohammad, J., \& Rasid, S. Z. A. (2018). Fraud prevention in Malaysian small and medium enterprises (SMEs). Journal of Financial Crime, 25(2), 499-517. https://doi.org/10.1108/JFC-052017-0049 
55. Srairi, S. (2018). Determinants of Corporate Risk Disclosure Practices: The Case of Islamic Banks in Gulf Cooperation Council Region. Journal of Muamlaat and Islamic Finance Research, 15(1), 21-50. https://doi. org/10.33102/jmifr.v15i1.99

56. Suryanto, T., \& Ridwansyah, R. (2016). The Shariah financial accounting standards: How they prevent fraud in Islamic banking. European Research Studies Journal, 19(4), 140-157. Retrieved from https://www.ersj.eu/repec/ers/papers/16_4_p12.pdf

57. Uzun, H., Szewczyk, S. H., \& Varma, R. (2004). Board composition and corporate fraud. Financial Analysts Journal, 60(3), 33-43. https://doi.org/10.2469/faj. v60.n3.2619
58. Vafeas, N. (1999). Board Meeting Frequency and Firm Performance. Journal of Financial Economics, 53(1), 113-142. https://doi.org/10.1016/S0304405X(99)00018-5

59. Vania, A. S., Nugraha, E., \& Nugroho, L. (2018). Does Earning Management Happen in Islamic Bank? (Indonesia and Malaysia Comparison). International Journal of Commerce and Finance, 4(2), 47-59. Retrieved from https://www.researchgate.net/ publication/329466320_Does_ Earning_Management_Happen_in_Islamic_Bank_Indonesia_and_Malaysia_Comparison

60. Westhausen, H. U. (2017). The escalating relevance of internal auditing as anti-fraud control.
Journal of Financial Crime, 24(2), 322-328. https://doi.org/10.1108/ JFC-06-2016-0041

61. Yulistyawati, N. K. A., Suardikha, I. M. S., \& Sudana, I. P. (2019). The analysis of the factor that causes fraudulent financial reporting with fraud diamond. Jurnal Akuntansi \& Auditing Indonesia, 23(1), 1-10. https://doi. org/10.20885/jaai.vol23.iss1.art1

62. Yusuf, A. D., Ahmad, U., \& Razimi, M. S. B. A. (2016). A Conceptual Study on Islamic Corporate Governance Model in Curtailing Bank's Fraud. International Journal of Economics, Finance and Management Sciences, 4(6), 357361. https://doi.org/10.11648/j. ijefm.20160406.17 